\title{
Effect of Marketing Practices on Credit Card Usage: The Mediating Role of Consumer Attitudes
}

\author{
Dorcas A. Kerre \\ Multimedia University of Kenya, Department of Marketing and Management
}

\begin{abstract}
Credit card use has gained popularity throughout the world. Banks introduce the credit card service as a way of improving their revenue streams. However, in Kenya, the rate of growth in usage has rather been slow. This research surveyed credit card holders in Nairobi, Kenya with a view to investigate the effect of marketing practices on credit usage and whether consumer attitudes had a mediating effect between the two factors. A cross-sectional survey was conducted by administering a structured questionnaire to 380 respondents. The study established that marketing practices affect credit card usage and that consumer attitudes did not significantly mediate the relationship between marketing practices and credit card usage. This paper makes a valuable contribution to managerial practice by showing how the elements of the extended marketing mix affect credit card usage. Thus it serves to inform the implementation of marketing strategy in banks by guiding on which aspects of marketing should be emphasised so as to increase credit card usage.
\end{abstract}

Key words: Marketing Practices, Credit Card, Consumer Attitudes, Kenya

DOI: 10.35942/jbmed.v1i1.55

\section{Cite this Article:}

Kerre, D. (2019). Effect of Marketing Practices on Credit Card Usage: The Mediating Role of Consumer Attitudes. Journal of Business Management, Entrepreneurship and Development, 1(1), 16-27. https://doi.org/10.35942/jbmed.v1i1.55

\section{Introduction}

Kenya is a developing country that is adopting use of technology to improve customer service delivery and to facilitate the country's development. The provision of credit card services has been made possible by technological advancement. In addition to credit cards, other non-cash payment methods include debit cards, online transfers and mobile money systems. An understanding of consumers' choice of these payment methods is therefore necessary. Credit cards were introduced in Kenya in 1967 by Diners Club, but it is not until the 1980's that growth in ownership began. However, the growth has been rather low (Financial Access survey, 2013) and this is of concern to those organizations that issue credit cards. Some credit cards can only be used to purchase from institutions that have issued them. These are referred to as retail cards. Bank credit cards can be used to make purchases from a range of merchants with whom the banks have contracts. This study focuses on bank credit cards. Some people use credit cards as a sign of power and prestige, while to others it allows incurring of expenses without worrying about the amount of money spent. There are two categories of credit cards users. Worthington (2005) uses the term "revolvers" to refer to those who do not pay what is owed at the end of the billing period and the term 'transactors' for those who pay what is owed at the end of the billing period. The former are also called instalment users and the latter, convenience users (Slocum \& Mathews, 1971).

World Bank (2017) ranks Canada top globally in credit card usage with $82.58 \%$ of adults owning credit cards followed by Israel (75\%) and then Norway (70.5\%). According to a report by McKinsey (2014), credit card use in Africa is significantly lower than that in other 
continents and in Kenya almost 9 out of 10 transactions are made in cash. The report attributes the low usage of credit cards to; the rural nature of most residences and lack of trust in the credit card system that has arisen from the high fraud rates in the region. Other factors that inhibit credit card growth in Africa are low levels of education, inadequate credit data, lack of information and inadequate supporting infrastructure. Andoh (2014) noted that although Ghanaians had a positive attitude towards credit cards, usage was deterred mainly by poor internet access and inadequate information.

South Africa has the highest credit card penetration in Africa (Lafferty Research Report, 2018). In 2015, the penetration was 31 cards per 100 adults. Egypt and Angola have penetration levels of 4 and 5 percent respectively. In Algeria, Ghana, Kenya, Morocco, Nigeria and Tunisia, penetration is 1 percent or below. Statistics on credit card usage in Kenya portray slow growth and fluctuations in ownership. Between December 2014 and December 2015, the number of credit cards owned increased by 50,000 but by May 2016, it had reduced by 36,000 (Central Bank of Kenya (2016). A study by Financial Sector Deepening (FSD) Kenya (2015) attributes the slow uptake of credit cards in Kenya to limited acceptance by merchants and fear of fraud. Marketing practices are the activities that organizations use to attract customers and ensure that service quality is maintained so as to achieve customer loyalty. Thus it is expected that marketing practices should increase credit card usage. Since marketing consumes significant resources, it is important to find out its impact on organizational performance. The service marketing mix was proposed by Booms and Bitner (1981) and its key elements are product, price, promotion, place, physical evidence, people and process. The analysis of marketing practices in this study was based on the service marketing mix.

Attitudes are a key determinant of consumer behaviour. Solomon et al. (2010) define attitude as a lasting and general evaluation of people, objects or issues. It is assumed that those who have a positive attitude towards a product or service are likely to purchase it. Wright (2006) argues that it is important to understand how consumers' attitudes about products are formed. Since attitudes affect consumer behaviour, various studies have been done to investigate the link between attitudes and credit card usage. Kinyua (2015) found a positive relationship between attitudes and credit card usage in Kitengela, Kenya. In a study done to find out determinants of attitudes towards credit card usage in Malaysia, Ismail et al. (2018) identified knowledge, awareness, perceptions and family influence as the key determinants. Qureshi et al. (2018) established that perceived risk was a key determinant of attitudes towards credit card usage in Pakistan. However, the relationship between attitudes and behaviour is not obvious as sometimes purchase may not take place even when one has a positive attitude towards an object. Banks invest heavily in marketing their services and so it is important to find out whether they get good returns on their investment. This study examines the effect marketing practices have on credit card usage by customers of banks and the mediating role of consumer attitudes.

\section{Research Problem}

The marketing function is important in business organizations that operate in a competitive environment. Marketing strategy developed should enable the achievement of organizational objectives and should be unique such that it provides a competitive advantage. Several studies have confirmed that marketing affects credit card usage (Zinman, 2009; Balasundram \& Ronald, 2006). Ekerete (2005) concluded that the marketing budgets of banks on Nigeria had a significant effect on their profitability. Kenya's banking sector has grown in terms of deposits, assets, profits and service offerings, thus increasing competition. Banks issue credit cards to improve their competitiveness and boost their financial position. However, the credit 
card service offered by banks has experienced minimal growth. In August 2018, only 250,000 Kenyans owned credit cards, whereas 3 million people were eligible (Barclays Bank of Kenya, 2018). Despite engaging in marketing, banks have not been able to increase credit card usage significantly. Thus there is need to investigate how the current marketing practices affect credit card usage, with a view to identifying specific variables within the marketing strategy that should be emphasised to increase uptake of credit cards.

Godwin (1998) attributed the increase in credit card use in the USA to change of attitudes towards credit. Other scholars (Kaynak \& Harcar, 2001; Phlau \& Woo, 2008) have found a positive relationship between attitudes and credit card usage. Studies examining credit card usage have focused mainly on effect of demographic variables (Fogel $\&$ Schneider, 2006; Gan et al. 2008; Teoh et al. 2013). Those studies that have included attitudes have considered it as an independent variable (Chan.1997). This study investigates how marketing practices affects credit card usage and the mediating effect of consumer attitudes.

\section{Objectives}

The study was guided by the following objectives:

a) To determine the effect of marketing practices on credit card usage in Kenya.

b) To establish the extent to which consumer attitudes affect the relationship between marketing practices and credit card usage in Kenya.

\section{Literature Review}

\subsection{Theoretical Foundation of the Study}

The main theory that guided the study is the theory of buyer behaviour (TBB). This theory creates an information processing model that integrates social, psychological and marketing influences on consumer choice. (Foxall, 1990). The key components in this theory are inputs, exogenous variables, intervening variables and outputs. Inputs are the factors in the environment that consumers are exposed to. These come in the form of products and services presented to consumers and information received through marketing communications. Exogenous variables are made up of family influence and reference groups. Consumers targeted by credit card marketers are influenced by information from credit card issuers, family members and other individuals they interact with. The intervening variables sift and sort the received stimuli and are categorized into personal constructs and learning constructs. Consumer attitudes fall in this category. Attitudes towards credit cards are learned overtime and are influenced by personal characteristics. Exogenous variables are the external factors that can influence consumer decisions and include social class, culture and financial status. Consumers may refrain from using credit cards because they believe their financial status cannot support their use. Outputs are the responses that buyers exhibit after processing received information. Consumers targeted by credit card issuers may respond by forming attitudes or acquiring credit cards.

\subsection{Credit Card Usage}

Credit cards are a mode of payment that enables buyers to make purchases even when they do not have cash at hand. This is possible because the card issuer extends credit to the user which can be paid in instalments over time with interest. They are issued by individual banks that are members of card associations (Visa, MasterCard, and American Express) or by other organizations (Chakravorti, 2003). The card associations are also called credit card networks. In Africa, Visa (57\%) and MasterCard (39\%) have the biggest presence (Nilsons Report, 2014). American Express is attempting to gain a foothold in the market and it has partnered with Equity Bank to offer credit cards in Kenya. Acquirers issue credit cards to consumers and they sign contracts with merchants who are willing to accept the cards for payment. 
Although credit cards were first introduced in the USA, the credit card market has grown in different parts of the world (Durkin \& Price, 2000). In UK, in 2015, there were 70 million credit cards in circulation (APACS, 2016) and the number of credit cards in Kenya in March 2018 was 242,346 (CBK, 2018). Credit cards offer an important payment method since online shopping is dominated by credit card usage (Thomas et al., 2005). Credit cards have been perceived to encourage impulse buying and so some consumers may avoid owning them so that they do not fall into that trap. Some benefits of using credit cards as a payment method are; opportunity to borrow money, convenience, security and most acceptable non cash payment method during foreign travel. In spite of these benefits, uptake of credit cards is still low in Kenya and since credit card issuers expect to generate revenue from that service, they have to engage in marketing activities to increase usage. However, all is not gloom as the future of the credit card market in Africa is good as a result of the growing middle class that has risen to $24 \%$ which is a $100 \%$ rise in 20 years (Africa Development Bank, 2018).

\subsection{Marketing Practices}

The marketing mix framework that dominates marketing management was originated in 1960 (McCarthy, 1978). This is made up of product, price, promotion and place. Over the years, improvements have been made to this framework to incorporate changes in the business environment. Booms and Bitner (1981) proposed the service marketing mix that extended the original marketing mix to include also people, process and physical evidence. Product refers to that which is offered to the target market while price is what consumers exchange for the offer. For credit cards the key features of the offer are: requirements for application, application approval period, instalment payment plan, grace period, credit card limit, minimum payment allowed and privacy of customer information (Kerre, 2018). For credit cards, the items that contribute towards price are; joining fee, annual fee, interest, late payment fee, cash advance fee and supplementary card annual fee. Teoh et al. (2013) found that requirements for application had no significant influence on credit card usage in Malaysia. In HongKong, grace period and a low annual fee were found to influence credit card ownership (Chan, 1997).

Promotion is the element of the marketing strategy that ensures communication with all the stakeholders. This can be done in different ways and these are advertising, personal selling, sales promotion, public relations and direct marketing (Kotler \& Armstrong, 2014). Advertising is non-personal communication that is conducted through the media (Berkowitz et al., 2000). Sales promotion provides short term incentives to encourage customers to use a product or service. Reward point systems and discounts are types of sales promotions that are applied by credit card issuers. Liu \& Brook (2009) noted that consumers' preference for reward point benefits differ from country to country. Personal selling is communication that enables face to face interaction with customers. Banks in Kenya use sales people to appeal to both current and potential customers. Public relations endeavours to build good relations with the company's publics through favourable publicity, creating a good corporate image and handling unfavourable situations. Direct marketing enables direct interactions with targeted customers. This is facilitated by technology and is mainly done through mobile and online media. . The promotion activities that were addressed in this study were: annual fee waiver, advertising, reward points, brochures, discounts, personal selling, online communication, short messaging service and email communication. The term 'place' is used to mean the distribution function of marketing. For bank services, direct distribution is largely used, because the services are inseparable and so are produced and consumed at the same time. As an element of the extended marketing mix, the term 'people' refers to those who are involved in service provision. Service personnel have an opportunity to play a promotional role during the service production process. Institutions develop procedures that guide the service delivery 
system and this is called 'process'. Ownership of credit cards may be influenced by the procedures that consumers have to go through when they apply for credit cards. Physical evidence captures the environment within which the service is provided and includes things like the interior decor, furniture and equipment in the service production area. These create a certain image that customers use to judge the quality of service being offered. The aim of marketing is to attract and retain customers and so this study examines the effect that marketing practices have on credit card usage.

\subsection{Consumer Attitudes}

Attitudes affect consumer behaviour and that is why some organizations carry out regular attitude surveys. Although attitudes are learned over time and are difficult to change, business organizations attempt to change unfavourable consumer attitudes. Studies have been done on the effect of attitudes on credit card usage. Durkin (2000) stated that attitude towards credit cards depends on how consumers use them and their experiences. He noted that installment users and those who owned more cards had unfavourable attitudes, while convenience users and those who owned fewer cards had more favourable attitudes. Heavy users of credit cards are likely to have a negative attitude towards credit cards because the high debt levels they incur are costly to manage. It is thus assumed that attitudes of credit card holders in Kenya should affect usage in terms of ownership, frequency of use as well as value of purchases. Measurement of attitudes can be done using different models. The multi-attribute model developed by Fishbein (1963) proposes that attitude towards an object is a summation of attitudes towards several attributes of the object. The three elements of the model are attribute, belief measure and importance weight. This model was used by Chan (1997) and Teoh et al. (2013) to measure attitudes of credit card holders. The other model is the Cognitive, Affective, Behaviour (CAB) model which classifies attitudes into affective, cognitive and behavioural components. Cognitive component measures beliefs about the actions taken or likely to be taken. In this study, the CAB model was used to operationalise attitudes.

\section{Conceptual Framework}

Based on the above review, the model below was developed to study the effect of marketing practices on credit card usage and the mediating effect of consumer attitudes.

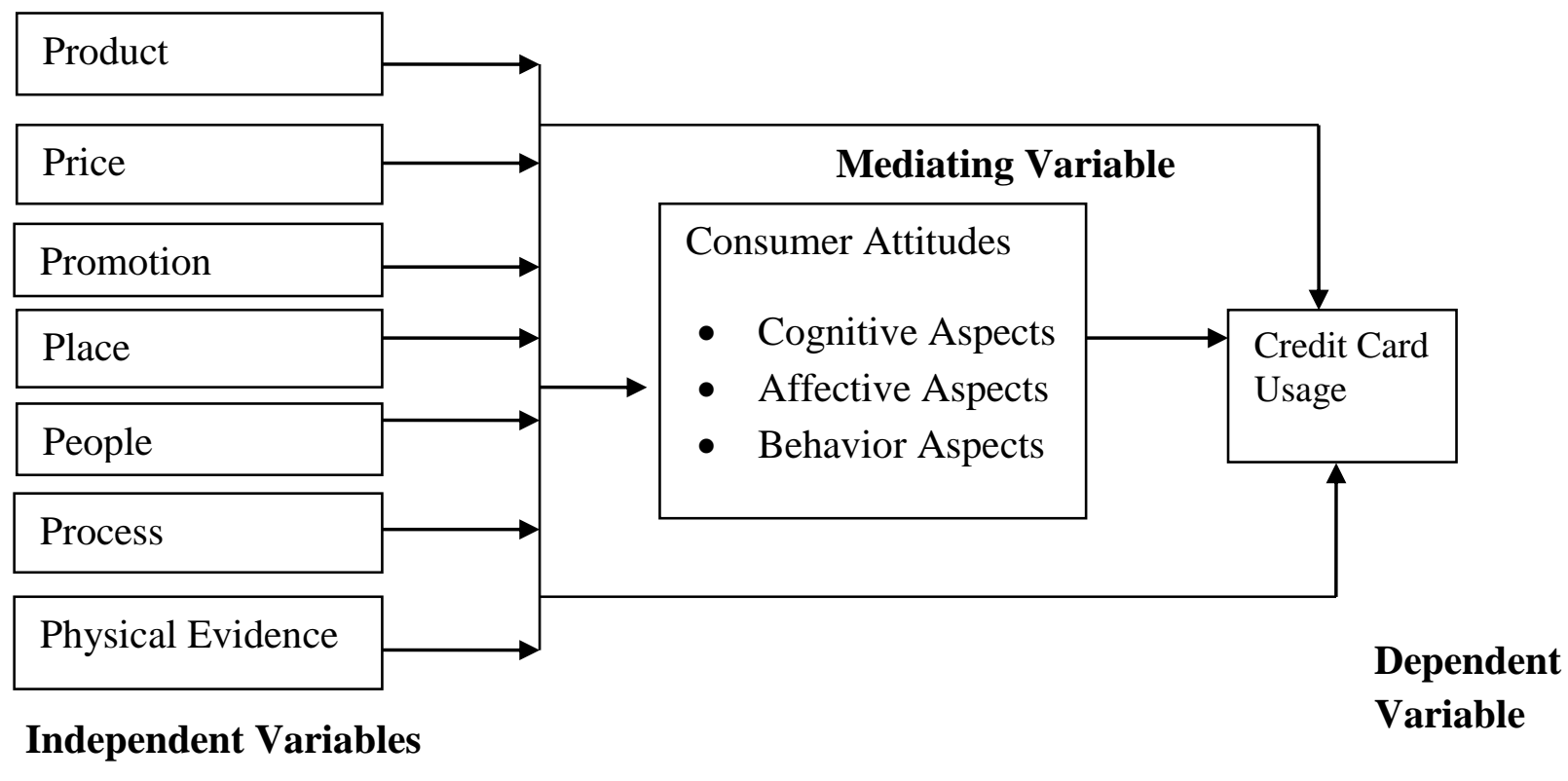

Figure 1: Conceptual Model 


\section{Hypotheses}

The hypotheses that were tested include:

HI: There is no significant relationship between product and credit card usage.

$\mathrm{H} 2$ : There is no significant relationship between price and credit card usage.

H3: There is no significant relationship between promotion and credit card usage

H4: There is no significant relationship between place and credit card usage.

H6: There is no significant relationship between process and credit card usage.

H7: There is no significant relationship between physical evidence and credit card usage.

H8: Consumer attitudes have no statistically significant mediating effect on the relationship between marketing practices and credit card usage.

\section{Methodology}

To test the above hypotheses, 380 credit card holders in Nairobi were interviewed using a structured questionnaire. The card holders were selected using stratified random sampling. The first clustering was done based on sub-divisions within Nairobi County and the second clustering was based on divisions. Nairobi was chosen because it has the highest usage rate for bank services. The mall intercept survey method was used to access the respondents. Large mall were used because they have many popular retail outlets and so are patronized by many people. Out of the 380 questionnaire distributed, 361 were duly filled and returned. The questionnaire used to collect primary data was divided into three sections. Section one focused on marketing practices under the sub-headings of product, price, promotion, place, people, process and physical evidence. Section two was on Consumer attitudes under the subheadings of cognitive aspects, affective aspects and behavioural aspects. Section three covered credit card usage with respect to ownership, usage, redemption of reward points and payment of credit balance. In all the sections, a 5 point Likert scale was used. The data collected was coded and analysed using Statistical Program for Social Sciences (SPSS) version 20. Descriptive statistics such as frequencies, percentages, mean scores and standard deviations were computed to explain the variables under study. Mean scores were correlated to ascertain the relationships. The Pearson Correlation Coefficient was used to determine the relationship between marketing practices and credit card usage and the Analysis of Variance was used to test the hypotheses. Stepwise multiple regression was used to test the mediating effect of consumer attitudes.

\section{Research Findings}

The research findings are stated below, beginning with effect of marketing practices. Table 1 presents responses on credit card holders' opinions about marketing practices of banks that issue credit cards.

Table 1: Responses on opinions about marketing practices

\begin{tabular}{|l|c|c|c|}
\hline & Mean & Standard deviation & $\begin{array}{c}\text { Coefficient of } \\
\text { Variation }\end{array}$ \\
\hline Product & 3.07 & 1.05 & 0.342 \\
\hline Price & 2.98 & 1.08 & 0.365 \\
\hline Place & 3.15 & 1.11 & 0.353 \\
\hline Promotion & 3.12 & 1.07 & 0.345 \\
\hline People & 3.12 & 1.07 & 0.345 \\
\hline Process & 3.18 & 1.09 & 0.345 \\
\hline
\end{tabular}


$=$ Journal of Business Management, Entrepreneurship and Development, Volume 1, Issue 1

\begin{tabular}{|l|c|c|c|}
\hline & Mean & Standard deviation & $\begin{array}{c}\text { Coefficient of } \\
\text { Variation }\end{array}$ \\
\hline Physical evidence & 3.15 & 1.10 & 0.353 \\
\hline Average & $\mathbf{3 . 1 1}$ & $\mathbf{1 . 0 8}$ & $\mathbf{0 . 3 4 9}$ \\
\hline
\end{tabular}

To find out if there was any association between marketing practices and credit card usage. Pearson correlation analysis was done and the results are presented in table 2.

Table 2: Pearson Correlation Coefficient results between marketing practices and credit card usage

\begin{tabular}{|l|c|c|}
\hline Marketing practices & R & Significance \\
\hline Product & 0.644 & 0.000 \\
\hline Price & 0.453 & 0.000 \\
\hline Promotion & 0.755 & 0.000 \\
\hline Place & 0.744 & 0.000 \\
\hline People & 0.740 & 0.000 \\
\hline Process & 0.728 & 0.000 \\
\hline Physical evidence & 0.703 & 0.000 \\
\hline
\end{tabular}

The findings revealed a significant positive correlation between each marketing variable and credit card usage. Correlation was highest with promotion $(r=0.755)$. This was followed by place (0.744) and then people (0.740). Therefore, all the marketing variables affect credit card usage. The Variance Inflation Factor (VIF) was computed to test for multicollinearity. All the VIF values were less than 10, thus ruling out multicollinearity. Regression analysis was then done to test the hypotheses and the results are presented in table 3.

Table 3: Regression results of Marketing Practices and Credit Card Usage

\begin{tabular}{|l|l|l|l|l|l|}
\hline & B & $\begin{array}{l}\text { Standard } \\
\text { Error }\end{array}$ & Beta & T & Significance \\
\hline Product & 0.105 & 0.038 & 0.126 & 2.74 & 0.006 \\
\hline Price & 0.15 & 0.031 & 0.191 & 4.863 & 0.000 \\
\hline Promotion & 0.148 & 0.04 & 0.199 & 3.721 & 0.000 \\
\hline Place & 0.157 & 0.048 & 0.195 & 3.289 & 0.001 \\
\hline People & 0.183 & 0.047 & 0.225 & 3.878 & 0.000 \\
\hline Process & 0.058 & 0.039 & 0.077 & 1.489 & 0.137 \\
\hline $\begin{array}{l}\text { Physical } \\
\text { evidence }\end{array}$ & 0.047 & 0.04 & 0.059 & 1.178 & 0.239 \\
\hline
\end{tabular}

Note: $F=136.133, p=0.000, R$ squared $=0.73$

$\mathrm{R}$ squared was found to be 0.73 and this shows that $73 \%$ of credit card usage is explained by marketing practices (product, price, promotion, place, people, process, physical evidence). Since the $\mathrm{p}$ value was 0 , there is a strong significant association between marketing practices and credit card usage. For all the marketing variables, the regression coefficients indicate a positive relationship with the dependent variable (credit card usage). Thus $\mathrm{H} 1, \mathrm{H} 2, \mathrm{H} 3, \mathrm{H} 4$, H5, H6 and H7 were all rejected.

To test the mediating effect of consumer attitudes on the relationship between marketing practices and credit card usage, stepwise multiple regression analysis was used. The four conditions that must be met for a mediation effect to be confirmed as stated by Baron and Kenny (1986) were used. The results are shown in table 4. 
Table 4: Mediation effect of Consumer Attitudes on Marketing Practices and Credit Card Usage

\begin{tabular}{|l|l|l|l|l|l|}
\hline & R squared & F & Beta & t & Sig. \\
\hline Step 1 & 0.722 & 932.54 & 0.8333 & 30.538 & 0.000 \\
\hline Step 2 & 0.196 & 87.441 & 0.384 & 9.351 & 0.000 \\
\hline Step 3 & 0.722 & 932.54 & 0.833 & 30.538 & 0.000 \\
\hline Step 4 & 0.739 & 507.224 & 0.124 & 4.847 & 0.000 \\
\hline
\end{tabular}

Step one reveals that the influence of marketing practices on credit card usage is statistically significant $(\mathrm{R}$ squared $=0.722, \mathrm{~F}=932.54, \mathrm{p}<0.5$ ). The beta coefficient was statistically significant $(\mathrm{B}=0.833, \mathrm{t}=30.538, \mathrm{p}<0.05)$. The first mediation rule which requires the independent variable to be statistically significantly correlated to the dependent variable without the presence of the mediating variable is therefore met. The second step shows that the influence of consumer attitudes on marketing practices was statistically significant ( $R$ squared $=0.196, \mathrm{~F}=87.441, \mathrm{p}<0.05)$, with $19.6 \%$ variation in marketing practices being influenced by consumer attitudes. The beta coefficient was statistically significant $(\mathrm{B}=$ $0.384, \mathrm{t}=9.351, \mathrm{p}<0.001)$, thus satisfying the second condition which requires that the independent variable be statistically significantly associated to the mediating variable.

In the third step, the influence of consumer attitudes on credit card usage was statistically significant ( $\mathrm{R}$ squared $=0.722, \mathrm{~F}=932.540, \mathrm{p}<0.05$ ). The beta coefficient was statistically significant $(\mathrm{B}=0.833, \mathrm{t}=30.538, \mathrm{p}<0.05)$ hence satisfying the third condition which states that the mediating variable should be significantly associated with the dependent variable. The last step indicated that the effect of the independent variable (marketing practices) on the dependable variable (credit card usage) was statistically significant in the presence of the mediating variable (consumer attitudes). $\mathrm{R}$ squared $=0.739, \mathrm{~F}=507.224, \mathrm{p}<0.05$ ). The beta was also statistically significant $(B=0.124, t=4.847, p<0.05)$, thus failing to satisfy the last requirement which states that the influence of the predictor variable on the dependent variable should be statistically non-significant in the presence of the mediating variable. The mediation test did not meet all the conditions that need to be satisfied for a mediating relationship to be confirmed. Thus the researcher failed to reject $\mathrm{H} 8$ and so it was concluded that consumer attitudes have no statistically significant mediating relationship between marketing practices and credit card usage.

\section{Conclusion}

The first part of the study looked at the influence of marketing practices on credit card usage. The findings revealed that marketing practices have a very high effect on credit card usage, accounting for $73 \%$ of the variability in credit card usage. For each of the marketing variables, there was a significant positive correlation with credit card usage. Promotion had the highest correlation $(\mathrm{r}=0.755)$. This suggests that decisions on each of these variables by credit card issuers would have an impact on usage. Other studies have found support for the relationship between marketing practices and credit card spending behaviour. Subramaniam and Marimuthu (2010) found that incentives given by banks and payment policies affected credit card usage. Simon et al. (2008) carried out a study in Australia and established that a loyalty card increases the chances of increasing credit card usage by $21 \%$ and interest free period increases usage by $15 \%$. Zinman (2009) highlighted interest free period as a key influencing factor. Gran et al. (2006) noted that the annual fee paid by credit card holders affected credit card selection in Singapore. Lunt (1992) found that factors that were important to credit card users were generous credit limit, quality customer service and a low interest 
rate. He also realized that many banks in USA used cash bonuses and no annual fee as promotional tools.

The second part of the study examined the extent to which consumer attitudes influence the relationship between marketing practices and credit card usage. The last condition for mediation as stated by Baron and Kenny (1986) was not met and so the conclusion is that consumer attitudes do not significantly mediate the relationship between marketing and credit card usage. However, this does not mean that attitudes do not affect credit card usage. The third step of the mediation test revealed that consumer attitudes have a direct effect on credit card usage. Other studies (Kerre, 2018, Phlau \& Woo 2008, Kaynac \& Harcar (2001) have found a positive relationship between attitudes and credit card usage. However, it should be noted that the relationship between attitudes and behaviour is complex and so positive attitudes towards credit may not necessarily lead to use of credit cards.

\section{Managerial Implication}

The study findings confirm that marketing plays a major role in determining consumer purchase behaviour. The effect of the extended marketing mix which is comprised of seven variables, that is, product, price, promotion, place, people, process and physical evidence was investigated. Each of these variables can be broken further into specific components and thus can provide information on areas that need to be emphasised. An example of a component of the credit card offer is credit card limit. Banks and other institutions that issue credit cards should ensure that they develop appropriate marketing strategies and provide the necessary resources to enable implementation. Secondly, the study findings can be used by marketing managers to garner support for the marketing function. There is need for the banks that issue credit cards to work together with the network associations such as Visa and MasterCard in order to promote primary demand for credit cards. The importance of extending the marketing mix to include people, process and physical evidence when operating in the service sector is also highlighted.

Attitudes influence consumer behaviour and credit card issuers need to carry out regular attitude surveys so that efforts can be made to influence attitudes where necessary. However, the influence of attitudes may be moderated by other factors and these should be taken into account. Chien and DeVaney (2001) mention the net effect of attitude on credit card use which is the effect after other factors such as demographic and economic factors have been considered. The attitude formation process is also important. Some consumers fear using credit cards because they do not fully understand how they operate. Credit card issuers should thus endeavour to disseminate adequate information to the target markets. This can be done through various media. Khalid et al. (2013) found that lack of awareness had a significant effect on credit card usage in Pakistan. Some consumers have unfavourable attitudes towards credit card use because of the troubles they have seen other users who have accrued heavy debts go through. Consumers need to be made aware that they can enjoy using credit cards without any unpleasant experiences.

\section{Limitations and Future Research}

One of the limitations of the study is that only credit card holders in Nairobi were sampled, leaving out those in other parts of the country. However, since Nairobi is a metropolitan city, it was possible to access respondents with a wide range of characteristics and generate useful insights in the credit card market. Another limitation is that charge cards were not included in the study although they also allow credit purchases only that they are restricted to specific retail outlets. The source of information for the study was restricted to credit card holders. 
Including non-credit card holders would have added value to the study by introducing the perspective of non-users.

Future research can be done that samples credit card holders from different parts of the country and includes charge cards. A comparison of the views of credit card and debit card holders would also be useful. Since credit card holders vary with respect to frequency of use, studies that compare active and inactive credit card holders would provide valuable information for operators in the credit card market.

\section{REFERENCES}

Balasundram, M. \& Ronald, E. (2006). Perspectives on credit card used and abuse. Journal of American Society of Business and Behavioural Sciences, Vol. 2, No. 1, 12-29

Baron, R.M. \& Kenny, D. (1986). The Moderator-Mediator Variable Distinction in Social Psychological Research: Conceptual, Strategic and Statistical Considerations. Journal of Personality and Social Psychology, Vol. 51, No. 6, 1173-1182

Barkowitz, E.N., Kerin, R.A., Hartley, S.W. \& Rudelius, W. (2000). Marketing. $6^{\text {th }}$ edition. Boston, Irwin.

Booms, B. \& Bitner, M.J. (1981). Marketing Strategies and Organizational Structures for Service Firms, in Donnelly, J.H. and W.R. George (eds). Marketing of Services, Chicago: American Marketing Association, 47-51.

Central Bank of Kenya (2018). Bank Supervision Annual Report

Chakravorti, S. (2003). Theory of Credit Card Networks: A survey of the literature. Review of Network Economies, Vol. 2. No.2, 50-68.

Chan, R. (1997). Demographic and Attitudinal differences between active and inactive credit cardholders - the case of HongKong. International Journal of Bank Marketing, Vol.15. No.4. $117-125$.

Chien, Y., \& DeVaney, S. (2001). The effects of Credit Attitude and Socioeconomic factors on Credit card and Installment debt. Journal of Consumer Affairs, Vol. 35, NO, 1, 162-179.

Durkin, T.A. (2000). Credit cards: Use and Consumer Attitudes, 1970-2000. Federal Service Bulletin, September, 621-634.

Durkin, T.A. \& Price, N. (2000). Credit cards: Use and Consumer Attitudes, Federal Reserve Bulletin, Vol.82, No. 9, 623-634.

Ekerete, P.P. (2005). Marketing of Financial Services - A case study of selected Merchant Banks in Nigeria. Pakistani Economic and Social Review, Vol. 63, No.2, 271-287.

Fishbein, M. (1963). An Investigation of the relationship between beliefs about an object and the attitude toward that object. Human Relations, Vol. 16. 233-40.

Fogel, J. \& Schneider, M. (2011). Credit card use: Disposable Income and Employment status: Young Consumers, Vol.12, No. 1, 5-14.

Foxall, G. (1990). Consumer Psychology in Behavioural Perspective. London. Routeledge

FSD Kenya (2015). Plastic card money on Kenya

FSD Kenya \& Central Bank of Kenya. (2013), Financial Access Survey. Nairobi, Kenya.

Gan, L.L., Masyami, R.C. \& Koh, H.C. (2008). Singapore Credit Cardholders: Ownership, Usage patterns and Perceptions. Journal of Services Marketing, Vol.22, No.4.267-279. 
Godwin, D.D. (1998). Household debt quintiles: Explaining changes 1983-1989. Journal of Consumer Affairs, Vol. 32, No. 2. 369-393.

http://www.afdb.org

http://www.barclays.co.ke

http://www.Mckinsey.com

http://www.nilsonreport.com

http://www.ukpayment.org.uk

Ismail, S., Amin, H., Shayeri, F.S. \& Hashim, N. (2014). Determinants of Attitudes towards Credit card usage. Journal Pengurusun, Vol.41. 145-154.

Kaynak, E., \& Harcar, T. (2000). Consumers' Attitudes and intentions towards Credit card Usage in an advanced developing country. Journal of Financial Services, Vol. 6, No. 1. 24-39.

Kerre, D.A. (2018). Effect of Marketing Practices, Consumer Demographics and Attitudes on usage of Credit cards by customers of Commercial Banks in Nairobi, Kenya. Unpublished PhD Thesis, School of Business, University of Nairobi.

Khalid, J., But, H.S., Murtaza, M., Khizar, U. (2013). Perceived barriers in the Adoption and Usage of Credit cards in Pakistan Banking Industry. International Review of Management and Business Research. Vol.2., No. 1, 104-116.

Kinyua, E. M. (2015). Influence of Consumer attitudes on the uptake of credit cards by customers of Commercial Banks within Kitengela Township, Kenya. Unpublished MBA project, University of Nairobi.

Kotler, P. \& Armstrong, G. (2005). Principles of Marketing. 11 ${ }^{\text {th }}$ edition, Pearson Education, PrenticeHall. Lafferty Research Report (2018)

Liu, T.M., \& Brock, J.L. (2009). Antecedents of Redemption of Reward Points: Credit Card Market in China and International Comparison. Journal of International Consumer Marketing, Vol. 22, No. 1, 33-45.

Lunt, P. (1992), What boosts credit card usage? American Bankers Association (ABA) Banking Journal, Vol. 84, No. 7, 82-85.

McCarthy, E.J. (1978). Basic Marketing. A Managerial Approach, 6th edition, Homewood, Richard Irwin.

McKinsey (2014). Research Report.

Nilsons (2014). Research Report

Phlau, I. \& Woo, C. (2008). Understanding compulsive buying techniques among young Australians: The roles of money attitude and credit card usage. Journal of Marketing Intelligence and Planning, Vol. 26, No. 5, 441-460.

Qureshi, J.A., Baqui, S. \& Qureshi, M.A. (2018). Consumer Attitudes towards usage of debit and credit cards: Evidences from the digital economy of Pakistan. International Journal of Economics and Financial Issues, Vol.8, No.5, 220-228.

Simon, J., Smith, K., West, T. (2008). Price incentives and Consumer payment patterns. Reserve Bank of Australia Payments PolicyDepartment, Working Paper. 
Solomon, M., Bamossy, G., \& Hogg, M. (2010). Consumer Behaviour: A European Perspective

Subramaniam, R., \& Marimuthu, M. (2010). Bank credit card and the selection criteria: An explanatory study. African Journal of Business Management, Vol. 4, No. 16, 36433472.

Slocum, J. \& Mathews, H.L. (1970). Social Class and Income as indicators of Consumer credit behaviour. Journal of Marketing, Vol. 16, No. 5, 211-220.

Schreft, S.L., (2006). How and why do consumers choose their payment methods? Federal Reserve Bank of Kansas City, Research Working Paper, No. 06-04.

Teoh, W., Chong, S.C., \& Yong, S. (2013). Exploring factors influencing credit card spending behaviour among Malaysians. International Journal of Bank Marketing, Vol. 31, No. 6, 481-500.

World Bank (2013). World Payment Report.

World Bank (2017). Global Economy.com

Wright, R. (2006). Consumer Behaviour. Cengage Learning. EMEA.

Zinman, J. (2009). Debit or Credit card? Journal of Banking and Finance, Vol. 2, No. 2, 358366. 